\title{
Strawberry Breeding in Canada
}

\author{
Hugh A. Daubeny \\ Agriculture Canada, Research Station, 6660 N.W. Marine Drive, Vancouver, B.C., V6T 1X2, Canada
}

For more than 20 years, strawberry production in Canada has relied almost entirely on cultivars developed by publicly supported breeding programs sponsored either by Agriculture Canada (federal government) or by the Ontario Ministry of Agriculture and Food (provincial government) (Dale, 1989; Daubeny, 1979; Galletta, 1979; Lawrence, 1989; Ourecky, 1979). Exceptions are a few minor cultivars developed by publicly supported programs in the United States.

Starting on the east coast, the Agriculture Canada program, located at the Kentville Research Station in Nova Scotia, has released eight cultivars since 1965. Several of the earlier releases are of major importance in production regions of eastern and central Canada and in the northeastern and midwestern United States. 'Bounty', released in 1972, was the first cultivar from the program to be widely planted. It was noted for its good fruit quality and late ripening season (Craig and Aalders, 1972). 'Micmac', released in 1976, has not been grown as extensively as 'Bounty' but has been important in the Maritime provinces. It has been a particularly valuable parent and is in the ancestry of three of the five more recently released Kentville cultivars (Jamieson and Nickerson, 1989). 'Kent', released in 1981, is currently the predominant cultivar in much of eastern and central Canada and is noted for its high yield (Craig et al., 1982). Four more recent releases, 'Glooscap', 'Blomidon', 'Annapolis', and 'Cornwallis', have better fruit firmness than the earlier releases. 'Glooscap' and 'Blomidon' are being widely planted (Dale, 1989; Luby, 1989). Similar to 'Kent', 'Glooscap' is a high yielder, but has the advantage of being more winter hardy. 'Blomidon' has exceptionally good fruit quality and eye appeal and it ships well (Jamieson and Nickerson, 1989). 'Annapolis' and 'Cornwallis' are resistant to red stele, caused by Phytophthora fragariae Hickman, a serious problem in parts of the Maritime provinces. Both are early ripening, which is an asset because most other cultivars from the program are mid- to late season.

Compared to most North American programs, the Kentville prograin has made greater use of European cultivars as parents (Jamieson and Nickerson, 1989). The use of such cultivars, which are relatively unrelated to many North American cultivars, is one of the three strategies suggested by Sjulin and Dale (1987) to increase genetic diversity. This use also might explain why 'Bounty' is one of the few North American cultivars, not withstanding those from California, that has had some acceptance in European production regions. It is now recommended in Norway and has attracted interest in the United Kingdom because of good fruit qualities (A.R. Jamieson, personal communication). Another of the cultivars, Kent, is showing promise in Sweden (Hancock and Scott, 1988).

The Ontario program, at the Horticultural Research Institute of Ontario (HRIO) located first at Vineland and, since 1983, at Simcoe, released four cultivars before 1950, two in 1967, three in 1980, and three since 1985 (A. Dale, personal communication). None released before 1950 had a major impact, but one, 'Valentine', has been an exceptionally useful parent in several breeding programs. In crosses with 'Sparkle', 'Valentine' resulted in two cultivars, Cavalier and Redcoat, from the now terminated Agriculture Canada program at the Ottawa Research Station, and 'Veestar' and 'Vibrant', the 1967 releases from the HRIO program. 'Valentine' also has been used extensively as a source of early ripening and low susceptibility to fruit rot (Botrytis cinerea Pers. ex. Fr.) by the Division of Fruit Breeding, Swedish Univ. of Agricultural Sciences, Balsgaard (Koch, 1963). The importance of 'Valentine' can be appreciated by the fact that 'Redcoat' and 'Veestar' were essentially

I thank C.J. Bishop, A. Dale, J.G.N. Davidson, A.R. Jamieson, and J.A. Sullivan for helpful contributions to this paper. the only cultivars planted in Ontario and Quebec from 1968 through 1980, when 'Kent' became important. 'Veestar' remains important as an early cultivar and 'Redcoat' still is important as a mid-season cultivar in some areas (Dale, 1989). Of the 1980 releases, only 'Vantage' is still grown; it is noted for resistance to leaf diseases and to verticillium wilt (Verticillium albo-atrum Reinke and Berth.). Of the recent releases from the program, 'Governor Simcoe' and 'Settler' have commercial potential. Both are extremely firm and produce large fruit suited to the fresh market (Dale, 1989; Dale et al., 1986).

The Ottawa program had a long history of cultivar development, starting in 1931 and ending in 1957. During this time, 17 cultivars were released. None of the earlier ones had a lasting impact. This lack of acceptance is attributed to virus infection and lack of knowledge, at that time, of virus eradication methods (C.J. Bishop, personal communication). Only 'Redcoat', of four 1957 releases, had a major impact. 'Redcoat' shows a good level of winter hardiness and has been a consistent producer of fruit with acceptable quality. 'Cavalier' had a limited impact for early fresh-market production (Darrow, 1966) before the wide-scale acceptance of 'Veestar'.

The Agriculture Canada program in British Columbia, first at the Agassiz Research Station and, since 1973, at the Vancouver Research Station, has released five cultivars. The first two, 'Agassiz' and 'Cheam', released in 1956 and 1969, respectively, were selected for winter hardiness after especially cold winters. Neither gained wide acceptance because of less-than-adequate fruit qualities. 'Totem', released in 1971, has dominated the B.C. industry for 15 years and now accounts for $\approx 80 \%$ of the plantings (Lawrence, 1989). It is also the most widely planted cultivar in the remainder of the Pacific Northwest production region. It replaced one of its parents, 'Northwest', which originated from the Washington State Univ. breeding program. 'Totem' produces large and firm fruit that is particularly suited to processing. These traits have also given the cultivar a small market in the United Kingdom and it is now considered promising in Romania (Hancock and Scott, 1988) and in Tasmania, Australia (C. Young, personal communication). The plants are virus-tolerant, relatively winter hardy, and have resistance to several of the common races of the red stele causal organism, P. fragariae. Two cultivars, Tyee and Sumas, were released from the program in the 1980s. 'Tyee' has succumbed to June yellows. 'Sumas', which is now being planted commercially, appears to offer a viable alternative to 'Totem' and is more winter hardy (Daubeny, 1987).

There had been a relatively small, but effective, Agriculture Canada program located at the Beaverlodge Research Station in northern Alberta. This program, now terminated, was unique because of its use of early generation derivatives of Fragaria virginiana glaucu Staudt and its northerly location, which permitted selection for extremely high levels of winter hardiness (J. Davidson, personal communication). In addition, selection for tolerance to abrupt changes in winter temperature was possible; the Beaverlodge area is subject to sudden, relatively high winter temperatures often followed by temperature drops as much as $-40 \mathrm{C}$. The program released 'Protern' in 1964 and 'Beaver Early', 'Beaver Sweet', 'Beaver Ruby', and 'Beaver Belle' in 1989. 'Protem', which produces fruit of good quality (but relatively small) has become the standard cultivar for small plantings and home gardens, especially in colder regions of the Prairie provinces (Harris, 1965). The 'Beaver' cultivars are improvements over 'Protem' for various traits, including yield. They appear to have the potential to increase strawberry production in regions subject to temperatures as low as $-40 \mathrm{C}$ with as little as 10 $\mathrm{cm}$ of snow cover.

Another unique strawberry breeding program in Canada was 
sponsored by the Ontario Ministry of Agriculture and Food in the Dept. of Horticultural Science at the Univ. of Guelph. The program produced two synthetic octoploid selections, ' $\mathrm{SO}_{1}$ ' and ' $\mathrm{SO}_{2}$ ' (Evans, 1982a, 1982b). ' $\mathrm{SO}_{1}$ ' was derived from colchicine-treated seed of a tetraploid hybrid of $F$. moschata Duch. $(2 \mathrm{n}=42)$ and $F$. nubicola Duch. $(2 \mathrm{n}=14)$. ' $\mathrm{SO}_{2}$ ' was derived from a tetraploid selection, which was obtained from colchicine-treated seed of a hybrid of two diploid species, $F$. vesca L. alpina Lund. $(2 \mathrm{n}=14)$ and $F$. virdis $\mathrm{L}$. $(2 \mathrm{n}=14)$, crossed with a tetraploid species, $F$. moupinensis (French) Card. $(2 \mathrm{n}=28)$. Seeds from the cross were subsequently colchicine-treated and from the resulting population the octoploid ' $\mathrm{SO}_{2}$ ' was selected. The two synthetic selections, which cross readily with the cultivated strawberry, offer germplasm not available at the octoploid level. This germplasm, which contains such traits as many upright flower stalks and distinctive flavors and aromas, is now being incorporated into the HRIO breeding program.

The wide-scale acceptance of cultivars such as 'Bounty', 'Kent', 'Redcoat', 'Totem', and 'Veestar', each developed by public programs, was instrumental in the expansion of the Canadian strawberry industry. Prior to introduction of these cultivars, the industry relied on those mostly developed by public programs in the United States or those selected initially as chance seedlings, either in Canada or the United States (Darrow, 1966). Among the latter, 'Marshall' and 'British Sovereign' were of considerable importance in B.C. (Darrow, 1966) and can be considered as contributions from the private sector. The only other contributions of any consequence from this sector are those of two nursery programs, one in Manitoba and the other in Saskatchewan, which released 17 and six cultivars, respectively, between 1940 and 1960. Several of these were grown in the Prairie provinces because of their winter hardiness and one, 'Glenheart', was a parent of 'Protem' and subsequently is in the derivations of two other Beaverlodge cultivars (Harris, 1965; J. Davidson, personal -communication\& None of this private cultivars is now grown in the Prairie provinces, which rely almost exclusively on 'Kent' and 'Redcoat' for commercial production (Dale, 1989).

Six publicly supported Canadian strawberry breeding programs have been described. The objectives of five of these have been to develop cultivars that allow profitable production of the crop under a wide range of environmental situations. There is no doubt that each of the programs has more than succeeded in meeting the objectives. At present, only three of the six are active. The termination of programs, such as those at Beaverlodge and Ottawa, both of which placed major emphasis on winter hardiness, is of concern. Improved winter hardiness would certainly benefit production in many regions of Canada. Immediate prospects, including the development of day-neutral cultivars, from the remaining programs are encouraging. Long-range prospects may not be as encouraging because there is a continuing erosion of public sector support for the programs. Thus, there is an ever-increasing reliance on privatesector support, which, in itself, is gratifying. There is, however, concern that this type of support may not be sustained over the relatively long period invoked in producing improved cultivars.
The concern is even greater if Fragaria species sources are being used as part of the program. The use of species germplasm is another one of the breeding strategies suggested by Sjulin and Dale (1987) to increase genetic diversity. It is obvious that this diversity is going to assume even more importance in future breeding efforts because of the necessity to reduce chemical usage for disease and pest control and, at the same time, increase production efficiency. It is imperative that Canadian breeding programs exploit the vast diversity existing in the indigenous octoploid Fragaria species, $F$. virginiana glauca, and $F$. chiloensis $\mathrm{L}$. Useful and potentially useful traits in these have been well-documented. Fortunately, Agriculture Canada has recently established a clonal germplasm repository that will stress indigenous fruit species. Thus, the necessary genetic diversity will be available for evaluation and subsequent use in breeding programs that have sustained support.

\section{Literature Cited}

Craig, D.L. and L.E. Aalders. 1972. Bounty strawberry. Can. J. Plant Sci. 52:849-850.

Craig, D.L., L.E. Aalders, and G.W. Bishop. 1982. Kent strawberry. Can. J. Plant Sci. 62:819-822.

Dale, A. 1989. Eastern Canada strawberry cultivars. Fruit Var. J. 43:3841.

Dale, A., V.P. Gray, and C.L. Rickeston. 1986. Governor Simcoe and Second strawberries. Can. J. Plant Sci. 66:1031-1032.

Darrow, G.M. 1966. The strawberry. Holt, Rinehart and Winston, New York.

Daubeny, H.A. 1979. The strawberry cultivars of the Pacific Northwest. Fruit Var. J. 33:44-45.

Daubeny, H.A. 1987. 'Sumas' strawberry. HortScience 22:511-513.

Evans, W.D. 1982a. Guelph $\mathrm{SO}_{1}$ synthetic octoploid strawberry breeding clone. HortScience 17:833-834.

Evans, W.D. 1982b. Guelph $\mathrm{SO}_{2}$ synthetic octoploid strawberry breeding clone. HortScience 17:834.

Galletta, G.J. 1979. Strawberry cultivars for eastern and midwestern North America. Fruit Var. J. 33:39-43.

Hancock, J.F. and D.H. Scott. 1988. Strawberry cultivars and worldwide patterns of strawberry production. Fruit Var. J. 42:102-108.

Harris, R.E. 1965. Protem strawberry. Can. J. Plant Sci. 45:299.

Jamieson, A.R. and N.L. Nickerson. 1989. Recent progress in breeding strawberries for Atlantic Canada. Acta Hort.

Koch, A. 1963. Valentine, ein beachtenswerter Kreuzungselter un der Erdbeerzuchtung. Der Züchter 33:352-354.

Lawrence, F.J. 1989. Pacific Northwest strawberry cultivars. Fruit Var. J. 43:19-21.

Luby, J.J. 1989. Midwest and Plain States strawberry cultivars. Fruit Var. J. $43: 22-31$

Ourecky, D.K. 1979. Strawberry cultivars of New York, New England and eastern Canada. Fruit Var. J. 33:38-39.

Sjulin, T.M. and A. Dale. 1987. Genetic diversity in North American strawberry cultivars. J. Amer. Soc. Hort. Sci. 11:375-385.

Trajkovski, K. and K. Nilsson. 1984. Strawberry variety trials at Balsgaard 1979-1983. Vaxtofordling Av Frakt och Bar Balsgaard Verksamets berattelse 1982-1983:49-70. 